\title{
Analisis Holoselulosa: Tinjauan Metode Analisis Kimia Konvensional
}

\author{
Chandra Apriana Purwita ${ }^{1,2, *}$, Henry Setiyanto ${ }^{2}$, Aminudin Sulaeman ${ }^{2}$ \\ ${ }^{1}$ Balai Besar Pulp dan Kertas, Jl. Raya Dayeuhkolot No. 132 Bandung, Indonesia \\ ${ }^{2}$ Program Studi Kimia, Institut Teknologi Bandung, Jl. Ganesha 10 Bandung, Indonesia
}

Diterima : 8 September 2020, Revisi akhir : 24 Desember 2020, Disetujui terbit : 30 Desember 2020

\section{Holocellulose Analysis: A Review of Conventional Chemical Analysis Methods}

\begin{abstract}
Holocellulose is a carbohydrate fraction that is a combination of cellulose and hemicellulose. Holocellulose fraction is important because it is the raw material used to be processed into various high-value products. Holocellulose content varies among various wood species. Holocellulose analysis is important to gain information on the characteristics and quality of raw materials, optimize the utilization of raw material sources, and improve process efficiency so that it is possible to commercialize the process of converting biomass into other high-economical materials. The principle of holocellulose analysis by conventional chemistry method is fractionation and isolation by removing lignin, extractives, and ash, but keeping cellulose and hemicellulose intact. Holocellulose analysis methods usually use the delignification method, using strong oxidizing reagents in low or high $\mathrm{pH}$ and high temperatures. Such methods include chlorine dioxide, chlorine-pyridine, chlorine-ethanol amine, chlor-1,4-dioxane, acid chlorite, and peracetic acid. The sodium chlorite method is widely used for the analysis holocellulose because of its simple separation procedure and rapid delignification. This article presents several holocellulose analysis methods, principles of determination, reactions, strengths, and weaknesses of each method to provide an overview for selecting the appropriate method and the accuracy of each method.
\end{abstract}

Keywords: holocellulose analysis, conventional analytical chemistry method, delignification

\section{Abstrak}

Holoselulosa merupakan fraksi karbohidrat yang merupakan gabungan antara selulosa dan hemiselulosa. Fraksi holoselulosa menjadi penting karena merupakan bahan baku yang digunakan menjadi berbagai produk yang memiliki nilai tinggi. Kandungan holoselulosa bervariasi di antara berbagai spesies kayu. Analisis holoselulosa penting untuk memperoleh informasi mengenai karakteristik dan kualitas bahan baku, mengoptimalkan pemanfaatan sumber bahan baku, dan meningkatkan efisiensi proses sehingga memungkinan komersialisasi proses konversi biomassa menjadi bahan lain yang berekonomis tinggi. Prinsip analisis holoselulosa metode kimia konvensional adalah fraksinasi dan isolasi yaitu dengan menyisihkan lignin, ekstraktif, dan abu, namun menjaga selulosa dan hemiselulosa tetap utuh. Metode analisis holoselulosa biasanya menggunakan metode delignifikasi, menggunakan reagen pengoksidasi kuat pada $\mathrm{pH}$ rendah atau tinggi dan suhu tinggi. Metode tersebut meliputi klor dioksida, klor-piridin, klor-etanol amina, klor-1,4-dioksan, klorit asam, dan asam perasetat. Metode natrium klorit banyak digunakan untuk analisis holoselulosa dengan karena prosedur pemisahan sederhana dan delignifikasi cepat. Artikel ini memaparkan sejumlah metode analisis holoselulosa, prinsip penentuan, reaksi, keunggulan dan kelemahan masing-masing metode sehingga dapat memberikan gambaran untuk memilih metode yang sesuai dan akurasi masing-masing metode tersebut.

Kata kunci: analisis holoselulosa, metode analisis kimia konvensional, delignifikasi 


\section{Pendahuluan}

Kayu dan non-kayu mengandung komponen utama yaitu holoselulosa dan lignin dengan kadar dapat mencapai $80 \%$ dari total berat bahan baku (Chen, 2014). Selain holoselulosa dan lignin, kayu dan non-kayu juga mengandung ekstraktif dan abu dengan kadar yang lebih rendah. Pada tanaman, selulosa dan hemiselulosa berfungsi memberi kekuatan pada struktur tanaman, sedangkan lignin merupakan komponen yang menyatukan serat (Basu, 2013). Selulosa merupakan polimer glukan yang terdiri atas unit $\beta-(1 \rightarrow 4)$ glukopiranosa, yang dihubungkan oleh ikatan glikosidik. Hemiselulosa merupakan polisakarida yang tersusun atas unit D-xilopiranosa, D-glukopiranosa, D-galaktopiranosa, D-arabino furanosa, D-manopiranosa, asam D-glukuronat, asam D-galakturonat dengan gula lainnya. Hemiselulosa juga mengandung gugus asetil dan metil tersubstitusi. Lignin merupakan polimer yang tersusun atas unit fenilpronana yaitu koniferil alkohol, p-kumaril alkohol, dan sinapil alkohol. Lignin sangat kompleks dan polimer lignin bersifat amorf yang tersusun secara tiga dimensi terdiri atas ikatan C-O-C dan C-C.

Perbedaan kandungan antara komponen kimia biomassa kayu dan non-kayu tersebut akan mempengaruhi reaktivitas kimianya. Oleh karena itu, informasi mengenai jumlah total masing-masing komponen sangat penting untuk dapat memahami karakteristik dan mutu bahan baku, mengoptimalkan pemanfaatan sumber bahan baku, dan meningkatkan efisiensi proses sehingga memungkinkan komersialisasi proses konversi biomassa menjadi bahan lain yang bernilai ekonomis tinggi.

Holoselulosa mengacu pada semua selulosa dan hemiselulosa dalam dinding sel tanaman. Holoselulosa diperoleh dari bahan baku dengan metode delignifikasi, menggunakan zat pengoksidasi kuat atau larutan asam atau basa pada suhu tinggi (Baeza and Freer, 2001). Kandungan holoselulosa bervariasi tergantung pada spesies, variasi biologis seperti perbedaan genetik pada spesies yang sama, dan kondisi pertumbuhan (Bajpai, 2018). Holoselulosa pada tanaman non-kayu cenderung lebih tinggi dibandingkan tanaman kayu. Holoselulosa pada rami (Cannabis sativa subsp. sativa) mencapai 86,08\% (Ateş et al., 2014). Holoselulosa bambu duri (Bambusa blumeana) yaitu $74,45 \%$, sedangkan bambu yang diproses dengan dekortikator lebih tinggi yaitu 83,47\% (Purwita and Sugesty, 2018). Holoselulosa pada tanaman kayu daun jarum sedikit lebih tinggi dibandingkan tanaman kayu daun lebar. Holoselulosa pada European aspen termasuk paling tinggi diantara golongan tanaman kayu daun jarum lainnya yaitu $82,68 \%$ (Gulsoy and Tufek, 2013) jika dibandingkan dengan Pinus brutia Ten yaitu 72,38\% (Durmaz et al., 2018). Acacia mangium dan Eucalyptus robusta tergolong tanaman kayu daun lebar dengan kandungan holoselulosa berturut-turut $85,99 \%$ dan $75,2 \%$ (Hou et al., 2016).

Holoselulosa menjadi bahan yang mendapatkan perhatian karena merupakan bahan baku yang digunakan untuk menghasilkan pulp dan kertas (Ramawat and Ahuja, 2016), holoselulosa nanofibril (Park et al., 2017), selulosa alfa (Sunardia et al., 2019), biokomposit (Yang et al., 2019), bioetanol (Vaz et al., 2016), aerogel (Huang et al., 2020).

Metode analisis holoselulosa bahan banyak menggunakan metode analisis kimia konvensional yang didasarkan pada fraksinasi bahan dilanjutkan dengan isolasi lebih lanjut untuk memurnikan dan mengkuantifikasi baik secara gravimetri maupun titrimetri (Carrier et al., 2011). Metode analisis holoselulosa banyak digunakan untuk memperoleh fraksi holoselulosa murni untuk dikonversi menjadi senyawa kimia lainnya. Meskipun metode analisis holoselulosa telah berkembang menggunakan instrumentasi seperti near-infrared spectroscopy (NIRS), akan tetapi metode tersebut memerlukan kalibrasi dari kumpulan data spektra terhadap kadar holoselulosa dari berbagi jenis spesies tanaman yang dianalisis dengan metode analisis kimia konvensional misalnya metode klorit asam (Ishizuka, Sakai and Tanaka-Oda, 2014; Kothiyal et al., 2015; Liang et al., 2020). Oleh karena itu akurasi dari metode kimia konvensional akan menentukan akurasi dari metode instrumentasi tersebut (Wu et al., 2018).

Prinsip analisis holoselulosa adalah dengan menyisihkan lignin, ekstraktif, dan abu, namun menjaga selulosa dan hemiselulosa tetap utuh. Metode tersebut meliputi klor dioksida, klorpiridin, klor-etanol amina, klor-1,4-dioksan, klorit asam, dan asam perasetat. Metode natrium klorit banyak digunakan untuk menentukan kandungan holoselulosa dengan keuntungan operasi pemisahan sederhana dan delignifikasi cepat (Chen, 2014). Metode analisis holoselulosa terus berkembang untuk mendapatkan hasil 
analisis yang akurat dan cepat. Dalam artikel ini, dipaparkan beberapa metode analisis holoselulosa menggunakan metode kimia konvensional, prinsip penentuan, reaksi, keunggulan dan kelemahan, serta akurasi masing-masing metode tersebut sehingga diharapkan dapat memberi gambaran mengenai pengembangan metode analisis holoselulosa.

\section{Metode Klor Dioksida}

Metode analisis holoselulosa pertama kali dikembangkan oleh Schmidt (Schmidt and Graumann, 1921) yang mengisolasi Skelettsubstanzen, fraksi karbohidrat yang mirip dengan holoselulosa. Kayu pinus diekstraksi selama 6 jam dengan larutan etanol benzena (1:2) untuk menyisihkan senyawa ekstraktif dan resin. Klor dioksida diproduksi dari hasil reaksi antara natrium klorat dan asam oksalat yang dipanaskan pada suhu $60^{\circ} \mathrm{C}$. Kayu bebas ekstraktif kemudian direaksikan dengan klor dioksida selama 24 jam. Residu dicuci dengan air. Sambil dipanaskan dalam penangas air, residu direaksikan dengan larutan natrium sulfit selama 1,5. Prosedur tersebut terus diulangi hingga memperoleh berat tetap. Reaksi delignifikasi dengan klor dioksida dan larutan natrium sulfit sangat lambat sehingga waktu analisis sangat lama, kira-kira satu bulan dan kelemahan metode ini terjadi degradasi karbohidrat.

\section{Metode Gas Klor}

Pada tahun 1933, Ritter dan Kurth mengembangkan metode analisis holoselulosa yang lebih cepat. Kayu maple diekstraksi menggunakan larutan etanol-benzena dilanjutkan dengan air panas. Kayu maple bebas ekstraktif dialirkan gas klorin selama 3-4 menit. Residu kemudian diekstraksi dengan alat Soxhlet menggunakan larutan etanol-piridin selama 2,5 jam yang berfungsi untuk menetralkan semua asam klorida yang terbentuk selama klorinasi dan untuk meningkatkan kelarutan klorolignin dalam air. Contoh dicuci dengan air dingin. Tahapan klorinasi dan ekstraksi diulang hingga diperoleh berat tetap. Prosedur tersebut menyisakan $1-2 \%$ lignin sehingga perlu untuk dilakukan delignifikasi lebih lanjut menggunakan larutan kalsium hipoklorit yang dinetralkan dengan asam asetat untuk menyempurnakan delignifikasi. Setelah diperlakukan dengan kalsium hipoklorit, rendemen holoselulosa lebih rendah yang mengindikasikan terjadi delignifikasi lebih lanjut untuk menyisihkan sisa lignin. Contoh direaksikan dengan larutan natrium hipoklorit selama 30 menit dalam bak perendam air es dengan suhu $10{ }^{\circ} \mathrm{C}$ sambil sesekali diaduk. Perlakuan contoh dengan larutan natrium hipoklorit cukup selektif untuk menyisihkan lignin karena hanya sedikit senyawa selain lignin yang terdegradasi. Rendemen dan kandungan holoselulosa pada metode ini mirip dengan Skekttsubstanzen namun memiliki kelebihan karena waktu analisis lebih singkat yaitu 10 jam. Ritter dan Kurth mengganti istilah Skelettsubstanzen dengan holoselulosa karena bahan tersebut mengandung selulosa dan hemiselulosa.

Prosedur tersebut dikembangkan lebih lanjut oleh Van Beckum dan Ritter (1937) dengan mengganti piridin dengan monoetanol amina. Contoh kayu bebas ekstraktif diperlakukan secara bergantian dengan gas klorin dan larutan panas 3\% monoetanol amina dalam etanol 95\%. Waktu analisis sekitar tiga jam. Klorinasi dan ekstraksi diulang sampai residu menjadi putih dan tidak berubah warna setelah ditambahkan pelarut monoetanol amina.

Serbuk kayu (60-80 mesh) disisihkan senyawa ekstraktifnya menggunakan etanol $95 \%$, etanolbenzena, dan air selama masing-masing 4 jam. Serbuk kayu ditempatkan pada cawan masir lalu dialirkan gas klor yang diproduksi dari kalsium klorit dan $\mathrm{HCl}$ selama 2 menit. Selama klorinasi contoh direndam dalam bak es karena gas klor bersifat eksoterm. Contoh berturut-turut dicuci dengan etanol $95 \%$ dan larutan monoetanol amina dalam etanol $\left( \pm 75^{\circ} \mathrm{C}\right)$ selama 2 menit. Prosedur tersebut terus diulangi hingga contoh berwarna putih dan tidak berubah warna menjadi coklat ketika dicuci dengan larutan monoetanol amina panas. Pencucian dilanjutkan dengan etanol, air dingin, alkohol, dan eter, lalu dikeringkan dalam oven. Prosedur ini kemudian digunakan sebagai metode analisis oleh Technical Association of the Pulp and Paper Industry (TAPPI) T 9 m-54Holocellulose in Wood, American Society for Testing and Materials (ASTM) D1104 - 1956 Edition - Method of Test for Holocellulose in Wood, dan diadopsi oleh Standar Nasional Indonesia (SNI) 01-1303-1989 - Cara uji kadar holoselulosa kayu.

Prosedur klorinasi dengan gas klor dan monoetanol amina dalam alkohol dikembangkan lebih lanjut oleh Holmes dan Kurth (Holmes 
dan Kurth, 1959) yang mengganti larutan 3\% monoetanol amina dalam etanol $95 \%$ dengan $5 \%$ monoetanol amina dalam 1,4-dioksan karena pelarut tersebut lebih efektif menyisihkan untuk klorolignin. Suhu reaksi diturunkan dari $75{ }^{\circ} \mathrm{C}$ menjadi $50{ }^{\circ} \mathrm{C}$.

\section{Metode Klorit Asam}

Metode klorit asam untuk analisis holoselulosa pertama kali dikembangkan oleh Jayme Wise dan Jahn pada tahun 1942 dan dimodifikasi oleh Wise et al. (1946). Jayme menggunakan natrium klorit dalam larutan asam untuk menjaga hemiselulosa secara kuantitatif agar tidak terdegradasi selama penentuan. Metode ini menghasilkan rendemen holoselulosa yang lebih tinggi dibandingkan dengan metode klor-etanol amina.

Natrium klorit bereaksi dengan asam untuk membentuk asam klorit yang kemudian terdekomposisi membentuk senyawa volatil klor dioksida sebagai produk utama, klorat dan ion klorida sebagai produk samping (Taylor et al., 1940). Reaksi natrium klorit pada suhu $60^{\circ} \mathrm{C}$ dan pH 3-5 sebagai berikut (Deshwal, Jo and Lee, 2004):

$4 \mathrm{ClO}_{2}^{-}+2 \mathrm{H}^{+} \rightarrow 2 \mathrm{ClO}_{2}+\mathrm{ClO}_{3}^{-}+\mathrm{Cl}^{-}+\mathrm{H}_{2} \mathrm{O} \ldots . .(1)$

Rasio molar klor dioksida terhadap ion klorat kirakira 2 (White, Taylor and Vincent, 1942). Reaksi dekomposisi klorit dalam asam dikatalis oleh ion klorida yang merupakan produk samping reaksi dekomposisi klorit. Reaksi klorit dengan adanya ion klorida sebagai berikut (Gordon, 1983):

$5 \mathrm{NaClO}_{2}+4 \mathrm{HCl} \rightarrow 4 \mathrm{ClO}_{2}+5 \mathrm{NaCl}+2 \mathrm{H}_{2} \mathrm{O} .$.

Reaksi natrium klorit pada suhu $95{ }^{\circ} \mathrm{C}$ adalah:

$5 \mathrm{ClO}_{2}^{-}+2 \mathrm{H}^{+} \rightarrow 4 \mathrm{ClO}_{2}^{-}+\mathrm{Cl}^{-}+2 \mathrm{OH}^{-}$.

Sejumlah kecil ion klorit dikonversi menjadi klorat dan beberapa klorit lainnya digunakan untuk membentuk oksigen bebas (Browning, 1967).

Prosedur analisis holoselulosa menurut Wise et al. (1946), serbuk contoh dengan ukuran 40-60 mesh ditimbang sebanyak 5 gram dan disisihkan ekstraktifnya melalui ekstraksi Soxhlet menggunakan pelarut etanol $95 \%$. Contoh dimasukkan ke dalam labu Erlenmeyer kemudian secara berturut-turut ditambahkan $160 \mathrm{~mL}$ air, $0,5 \mathrm{~mL}$ asam asetat glasial, dan 1,5 g natrium klorit lalu dipanaskan selama 1 jam pada suhu $70-80{ }^{\circ} \mathrm{C}$ dalam penangas air. Penambahan asam asetat glasial dan natrium klorit terus diulang setelah satu jam. Empat siklus klorinasi biasanya diperlukan untuk tanaman kayu daun jarum, sedangkan tanaman kayu daun lebar memerlukan tiga kali siklus. Setelah siklus klorinasi berakhir, labu Erlenmeyer ditempatkan pada bak perendam es dan didinginkan hingga suhu $10^{\circ} \mathrm{C}$. Residu holoselulosa kemudian disaring menggunakan cawan masir dan dicuci dengan aseton, diekstraksi dengan etanol 95\% dalam Soxhlet, dicuci dengan air dingin lalu dikeringkan dalam oven $105^{\circ} \mathrm{C}$.

\section{Modifikasi Metode Klorit Asam dengan Koreksi Kadar Lignin, Abu, dan Protein}

Metode analisis komponen kimia kayu tidak sepenuhnya cocok untuk untuk spesies biomassa non-kayu. Hal ini disebabkan selain selulosa, hemiselulosa, lignin, ekstraktif, dan abu, beberapa jenis non-kayu juga mengandung komponen lain seperti pati dan protein yang menyebabkan total kandungan komponen kimia bahan kurang atau lebih dari 100\% (Sari et al., 2015; Kaur et al., 2016). Pati memiliki kelarutan yang rendah pada aseton atau etanol-benzena. Tahapan ekstraksi menggunakan pelarut tersebut kurang efektif untuk menyisihkan pati. Karena pati larut dalam air panas, maka perlu dilakukan modifikasi persiapan bahan baku untuk analisis holoselulosa yaitu dengan melakukan pencucian menggunakan air panas pada contoh bebas ekstraktif. Jika pencucian dengan air panas tidak dilakukan, dikhawatirkan pati akan mengkontaminasi fraksi holoselulosa yang menyebabkan kadar holoselulosa lebih tinggi dari yang sebenarnya terutama pada contoh yang mengandung kadar pati tinggi misalnya bambu.

Atom $\mathrm{Na}$ dan $\mathrm{Cl}$ terbentuk sebagai produk samping hasil reaksi natrium klorit pada analisis holoselulosa menyebabkan kontaminasi pada residu holoselulosa sehingga kadar holoselulosa lebih besar dari kadar sebenarnya. Percobaan untuk mengamati kontaminan anorganik pada fraksi holoselulosa dan lignin yang diperoleh dari hasil analisis jerami telah dilakukan oleh Saka dan Mimori (1994). Fraksi holoselulosa dan lignin diabukan kemudian dianalisis dengan spektroskopi sinar-X dispersif energi (EDX). Hasilnya kemudian dibandingkan dengan abu yang diperoleh dari bahan baku. Seperti terlihat pada Gambar 1, munculnya puncak atom $\mathrm{Na}$ dan 
naiknya intensitas atom $\mathrm{Cl}$ pada spektrum EDX abu dari fraksi holoselulosa mengindikasikan adanya kontaminasi atom $\mathrm{Na}$ dan $\mathrm{Cl}$ yang kemungkinan berasal dari pereaksi natrium klorit. Meskipun pada analisis holoselulosa dilakukan proses pencucian, akan tetapi atom $\mathrm{Na}$ dan $\mathrm{Cl}$ masih terdeteksi pada fraksi holoselulosa. Tingginya kandungan zat mineral pada nonkayu menyebabkan kontaminasi pada residu holoselulosa dan lignin Klason sehingga analisis lignin dan holoselulosa perlu dilakukan koreksi kadar abu dan protein untuk mendapatkan hasil analisis dengan akurasi tinggi (Rabemanolontsoa and Saka, 2012).

Rabemanolontsoa and Saka (2011) serta Rabemanolontsoa and Saka (2012) melakukan analisis holoselulosa pada 6 jenis spesis kayu dan non-kayu. Spesis kayu diwakili oleh cedar jepang (Cryptomeria japonica) dan beech jepang (Fagus crenata), dan spesis non-kayu diwakili oleh bambu (Phyllostachys heterocycla), sargasum (Sargassum horneri), padi (Oryza sativa), jagung (Zea mays), dan kelapa sawit (Elaeis guineensis).

Metode analisis holoselulosa yang digunakan merupakan modifikasi metode klorit asam Wise et al. (1946). Sebanyak 2,5 gram contoh bebas ekstraktif ditambahkan $150 \mathrm{~mL}$ bufer asam asetat 0,2 Myang menggantikan air sebagai media reaksi yang merupakan modifikasi prosedur Timell (1961). Ke dalam larutan tersebut ditambahkan 1 gram natrium klorit dan $0,2 \mathrm{~mL}$ asam asetat glasial kemudian dipanaskan dalam penangas air selama 1 jam pada suhu $70-80^{\circ} \mathrm{C}$. Natrium klorit dengan asam asetat ditambahkan selama selang waktu 1 jam. Larutan kemudian disaring, dicuci dengan air dan aseton. Kandungan holoselulosa kemudian ditentukan secara gravimetri.

Seiring dengan penambahan jumlah siklus klorinasi, residu contoh yang berwarna coklat akan memudar menjadi kekuningan, dan kemudian keputihan (Gambar 2). Klorinasi biasanya dilakukan hingga contoh berubah keputihan, namun dengan bertambahnya siklus klorinasi maka rendemen holoselulosa akan lebih rendah karena terjadi degradasi karbohidrat (Rabemanolontsoa and Saka, 2011).

Seperti terlihat pada Gambar 2, setelah 5 kali siklus klorinasi pada bambu, rendemen holoselulosa turun yang disebabkan oleh terjadinya hidrolisis karbohidrat menjadi gulagula sederhana yang larut pada air (Ely and Moore, 1955). Oleh karena itu, untuk mendapatkan hasil analisis yang akurat maka siklus klorinasi dilakukan hanya hingga contoh berwarna kekuningan lalu dilakukan koreksi lignin dan abu pada residu holoselulosa (Rabemanolontsoa and Saka, 2011). Sebanyak 3 kali siklus klorinasi untuk kayu daun lebar, 4 kali untuk kayu daun jarum dan maksimal 5 kali untuk non-kayu. Contoh dengan kandungan protein tinggi seperti sargasum dan daun jagung, koreksi protein juga harus dilakukan karena protein pada kayu

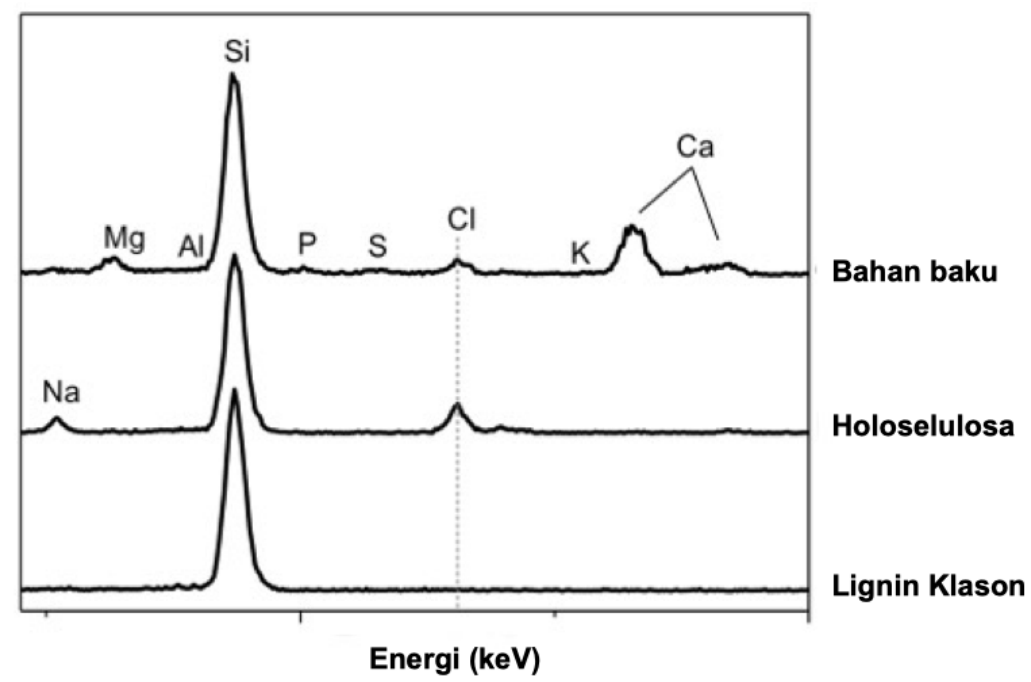

Gambar 1. Perbandingan relatif spektrum sinar-X dispersif energi pada abu bahan baku jerami padi, fraksi holoselulosa dan lignin hasil analisis yang ditentukan oleh analisis EDX (Saka dan Mimori, 1994). 
memiliki kelarutan yang rendah pada pelarut yang digunakan untuk ekstrasi misalnya aseton, tetapi mudah larut dalam larutan bufer dan selama analisis holoselulosa protein tidak terdegradasi oleh bahan kimia (Bao, O'Malley and Sederoff, 1992; Rabemanolontsoa and Saka, 2012). Analisis lignin pada residu holoselulosa ditentukan tidak hanya berasal dari lignin tak larut asam atau lignin Klasson, tetapi karena residu holoselulosa mengandung senyawa lignin yang termodifikasi yang tidak dapat ditentukan dengan asam sulfat $72 \%$ dan senyawa lignin tersebut kehilangan kemampuan kondensasi ketika dioksidasi oleh natrium klorit (Suzuki, 1953). Oleh karena itu, kandungan lignin ditentukan berdasarkan jumlah total dari lignin larut dan tak larut asam (Yoshihara et al., 1984). Kadar abu ditentukan secara gravimetri berdasarkan pengabuan contoh pada suhu $600{ }^{\circ} \mathrm{C}$ selama 4 jam dan kadar protein ditentukan dengan metode Kjeldahl (Thiex et al., 2002).

Modifikasi metode tersebut memungkinkan untuk melakukan analisis holoselulosa pada sebagian besar contoh biomassa baik kayu dan non-kayu dengan hasil analisis dengan akurasi yang lebih baik.

\section{Modifikasi Metode ASTM dengan Meningkatkan Suhu dan Mempersingkat Waktu Reaksi}

Metode standar analisis holoselulosa (ASTM D1104-56 (1978)) dikembangkan umumnya untuk tanaman berserat terutama untuk kayu

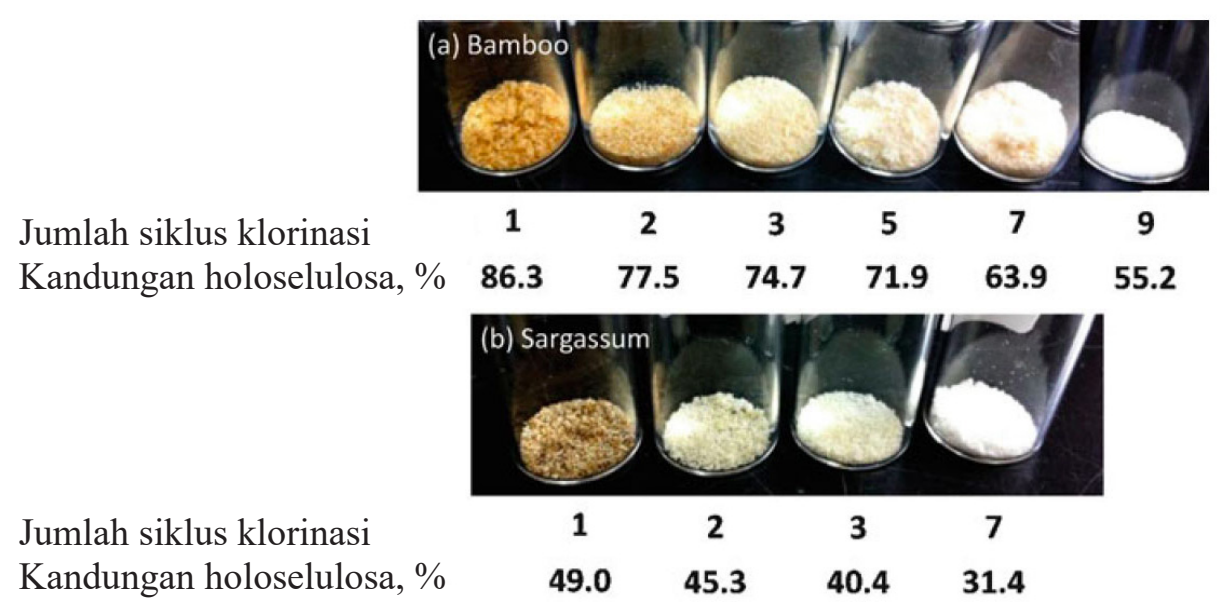

Gambar 2. Residu holoselulosa dari (a) bambu dan (b) sargasum setelah berbagai siklus klorinasi (Rabemanolontsoa and Saka, 2011)

\section{a}

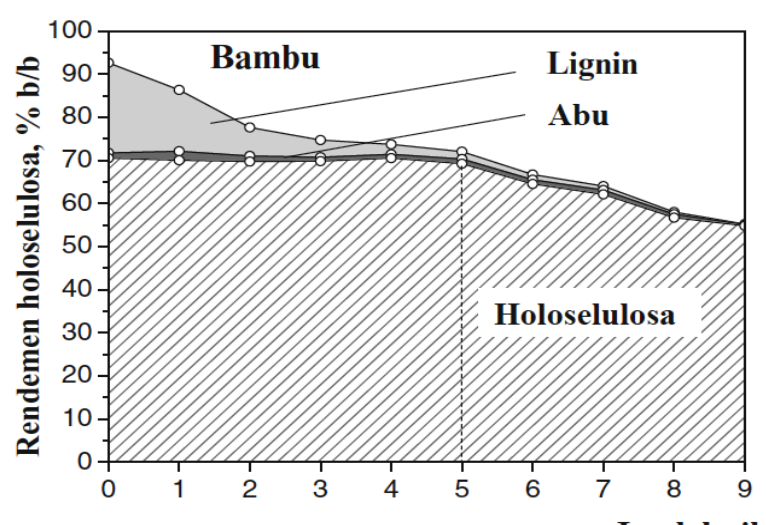

b

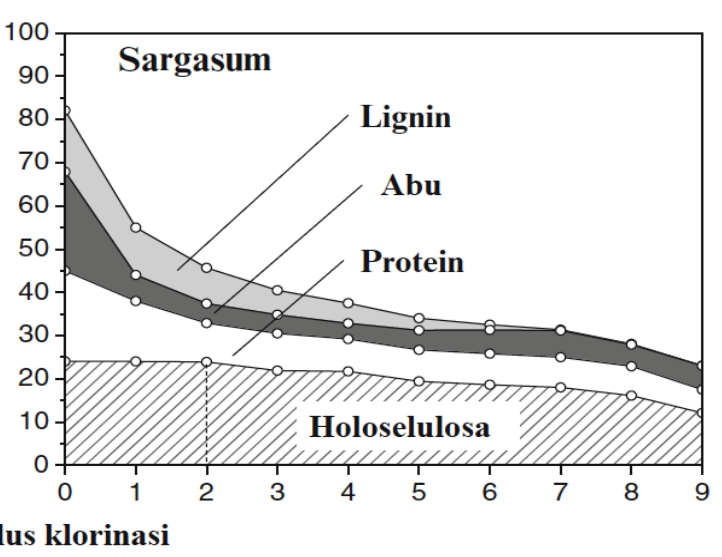

Gambar 3. Perubahan rendemen holoselulosa, lignin, dan abu selama klorinasi pada bambu (kiri) dan sargasum (kanan) (Rabemanolontsoa and Saka, 2011) 


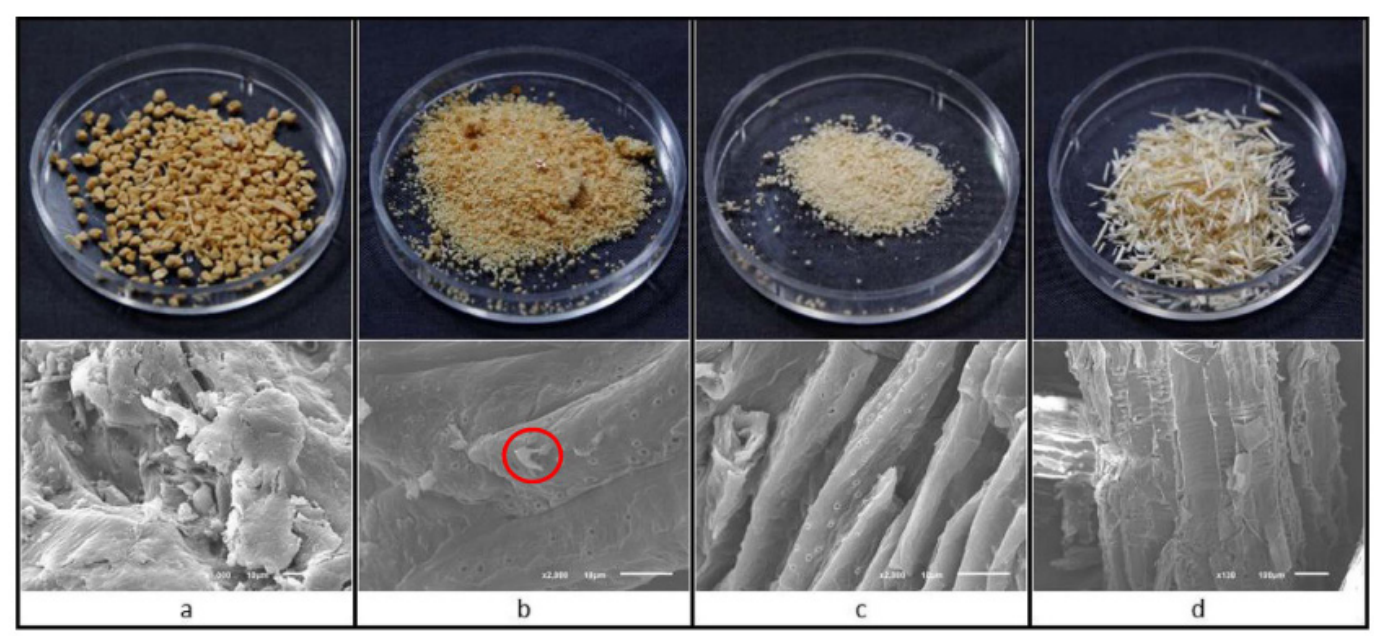

Gambar 4. SEM mikrograf biomassa dan fraksi holoselulosa. (a) biji zaitun, (b) fraksi holoselulosa biji zaitun yang diperoleh pada $70-80^{\circ} \mathrm{C}$ mengikuti metode standar, (c) fraksi holoselulosa biji zaitun diisolasi dengan metode yang dimodifikasi, (d) holoselulosa pohon ceri diperoleh dengan mengikuti metode standar (Rabemanolontsoa and Saka, 2011)

dan kurang cocok untuk non-serat seperti biji, cangkang, kernel karena kecenderungannya memberikan hasil yang lebih tinggi dari nilai sebenarnya yang disebabkan oleh rendahnya delignifikasi contoh oleh klorit asam. Oleh karena itu, pengembangan metode analisis holoselulosa perlu dilakukan dengan meningkatkan degradasi lignin dan meminimalkan degradasi fraksi karbohidrat dan mempersingkat waktu analisis (Álvarez et al., 2018).

Sebelum analisis, contoh diekstraksi dua kali menggunakan Soxhlet selama 7-8 kali masingmasing menggunakan aseton dan air untuk menyisihkan senyawa ekstraktif seperti resin, wax, sterol, tanin, lemak, asam lemak, gum, gula, dan senyawa berwarna lainnya (Taflick et al., 2017; Kumar et al., 2020). Sebanyak $5 \mathrm{~g}$ contoh biomassa tak-berserat yang bebas ekstraktif dimasukkan gelas kimia kemudian ditambahkan $150 \mathrm{~mL}$ air, $5 \mathrm{~g}$ natrium klorit, dan $1,08 \mathrm{~mL}$ asam asetat glasial. Suhu reaksi lebih tinggi dibandingkan metode ASTM yaitu $96{ }^{\circ} \mathrm{C}$ dengan waktu yang lebih singkat yaitu 90 menit. Hasil kemudian dibandingkan dengan hasil yang diperoleh dengan menggunakan metode ASTM.

Fraksi holoselulosa yang diperoleh dianalisis menggunakan SEM. Tingginya kandungan lignin pada biji zaitun menyebabkan struktur serat kasar (Gambar 4a). Foto serat fraksi holoselulosa pada biji zaitun yang diperoleh dengan metode standar masih menunjukkan adanya lignin yang ditunjukkan dengan lingkaran (Gambar 4b).
Fraksi holoselulosa yang diperoleh dengan metode yang dimodifikasi menunjukkan permukaan serat yang lebih halus (Gambar 4c). Hasil ini menunjukkan bahwa prosedur penetapan holoselulosa standar tidak cocok untuk contoh biomassa non-kayu karena metode tersebut tidak mampu melakukan delignifikasi sempurna pada contoh, tetapi dengan metode yang dimodifikasi mampu menyisihkan lignin dengan lebih baik namun tidak mempengaruhi kandungan karbohidrat pada fraksi holoselulosa yang dibuktikan analisis monomer pada fraksi holoselulosa menggunakan HPLC.

Indeks kristalinitas fraksi holoselulosa yang diperoleh dengan menggunakan metode yang dimodifikasi tidak berubah meskipun analisis menggunakan suhu reaksi yang lebih tinggi dibandingkan metode standar. Hal tersebut dibuktikan oleh difraktogram contoh yang kemudian dibandingkan dengan microcrystalline cellulose (MCC) sebagai bahan acuan. Selain itu, tidak ada perbedaan signifikan antara komposisi monomer kedua fraksi holoselulosa sehingga dapat disimpulkan bahwa suhu yang lebih tinggi dari metode baru dapat meningkatkan proses delignifikasi tanpa mempengaruhi kandungan karbohidrat.

\section{Kesimpulan}

Metode klorit asam merupakan metode analisis holoselulosa yang paling banyak 
digunakan karena prosedurnya sederhana dan proses delignifikasi cepat. Namun demikian, metode tersebut tidak sepenuh cocok untuk berbagai jenis bahan baku. Misalnya tanaman non-kayu yang mengandung komponen kimia lain seperti pati, protein, dan kandungan abu tinggi. Oleh karena itu fraksi holoselulosa harus dikoreksi terhadap kadar pati, protein, dan abu karena komponen tersebut ikut tertimbang secara gravimetri pada fraksi holoselulosa. Bahan baku yang tidak berserat seperti biji, cangkang, dan kernel juga tidak cocok menggunakan metode klorit asam karena metode tersebut didisain untuk tanaman kayu yang berserat. Ketidakmampuan metode analisis untuk mencapai pemisahan yang tepat dari fraksi lignin dan holoselulosa dari bahan baku menyebabkan akurasi analisis holoselulosa menjadi rendah sehingga perlu dilakukan pengembangan metode analisis holoselulosa dengan melakukan optimasi proses delignifikasi bahan. Variasi dosis reagen, suhu, $\mathrm{pH}$, waktu reaksi dilakukan sehingga diharapkan hasil analisis yang diperoleh akan lebih akurat dan waktu analisis lebih cepat.

\section{Daftar Pustaka}

Álvarez, A., Cachero, S., González-sánchez, C., Montejo-bernardo, J., Pizarro, C. and Bueno, J. L. (2018) 'Novel method for holocellulose analysis of non-woody biomass wastes', Carbohydrate Polymers. 189, pp. 250-256. doi: 10.1016/j.carbpol.2018.02.043.

Amini, M. H. M., Rasat, M. S. M., Ahmad, M. I., Wahab, R., Elham, P., Wan, W. M. N. A. R. and Ramle, N. H. (2017) 'Chemical composition of small diameter wild Acacia mangium species', ARPN Journal of Engineering and Applied Sciences, 12(10), pp. 3169-3173.

Ateş, S., Deniz, İ., Kirci, H., Atik, C. and Okan, O. T. (2014) 'Comparison of pulping and bleaching behaviors of some agricultural residues', Turkish Journal of Agriculture and Forestry, 39(1), pp. 144-153. doi: 10.3906/ tar-1403-41.

Baeza, J. and Freer, J. (2001) 'Chemical Characterization of Wood and Its Components', in Hon, D. N.-S. and Shiraishi, N. (eds) Wood and Cellulosic Chemistry. 2nd Editio. New York: Marcel Dekker, pp. 275-384.

Bajpai, P. (2018) Biermann's Handbook of Pulp and Paper. 3rd edn, Biermann's Handbook of Pulp and Paper. 3rd edn. Amsterdam: Elsevier. doi: 10.1016/c2017-0-00530-x.
Bao, W., O'Malley, D. M. and Sederoff, R. R. (1992) 'Wood contains a cell-wall structural protein', Proceedings of the National Academy of Sciences of the United States of America, 89(14), pp. 6604-6608. doi: 10.1073/pnas.89.14.6604.

Basu, P. (2013) Biomass Gasification, Pyrolysis and Torrefaction: Practical Design and Theory. Second, Biomass Gasification, Pyrolysis and Torrefaction: Practical Design and Theory. Second. London: Academic Press. doi: 10.1016/C2011-0-07564-6.

Van Beckum, W. G. and Ritter, G. J. (1937) 'Rapid method for determination of holocellulose and cross and bevan cellulose in wood', Paper Trade Journal, 104(19), pp. 49-50.

Browning, B. L. (1967) Methods of Wood Chemistry. New York: Interscience Publishers.

Carrier, M., Loppinet-Serani, A., Denux, D., Lasnier, J. M., Ham-Pichavant, F., Cansell, F. and Aymonier, C. (2011) 'Thermogravimetric analysis as a new method to determine the lignocellulosic composition of biomass', Biomass and Bioenergy, 35(1), pp. 298-307. doi: 10.1016/j.biombioe.2010.08.067.

Chen, H. (2014) Biotechnology of Lignocellulose, Biotechnology of Lignocellulose. Beijing: Chemical Industry Press and Springer. doi: 10.1007/978-94-007-6898-7.

Deshwal, B. R., Jo, H. D. and Lee, H. K. (2004) 'Reaction kinetics of decomposition of acidic sodium chlorite', Canadian Journal of Chemical Engineering, 82(3), pp. 619-623. doi: $10.1002 /$ cjce.5450820323.

Durmaz, E., Ateş, S., Abuamoud, M. M. M. and Yiğit, N. (2018) 'Comparison of some anatomical, chemical and fibrous characteristics of Turkish Pine (Pinus Brutia Ten.) sampled from different regions', Kastamonu Üniversitesi Orman Fakültesi Dergisi, 18(1), pp. 75-82. doi: 10.17475/ kastorman.364592.

Ely, R. E. and Moore, L. A. (1955) 'Yields of holocellulose prepared from ruminant feces by acid chlorite treatment', Journal of Dairy Science. Elsevier, 38(9), pp. 1017-1022. doi: 10.3168/jds.S0022-0302(55)95071-2.

Gordon, G. (1983) 'Improved methods of analysis for chlorate, chlorite and hypochlorite ions at the sub-mg/L level', Proceedings - $A W W A$ Water Quality Technology Conference, pp. 175-189.

Gulsoy, S. K. and Tufek, S. (2013) 'Effect of chip mixing ratio of Pinus pinaster and Populus tremula on Kraft pulp and paper properties', Industrial \& Engineering Chemistry Research, 52(6), pp. 2304-2308. doi: 10.1021/ ie302709e. 
Holmes, G. W. and Kurth, E. F. (1959) 'Improvements in the determination of holocellulose', Technical Association of Pulp and Paper Industry, 42, pp. 837-840.

Hou, Y., Liu, C., Xu, J., Li, Y. and Hu, S. (2016) 'Application of alkaline ionic liquids in the pretreatment process of eucalyptus kraft pulping', Bio Resources, 11(4), pp. 90369046.

Huang, H., Yu, Y., Qing, Y., Zhang, X. and Cui, J. (2020) 'Ultralight industrial bamboo residue-derived holocellulose thermal insulation aerogels with hydrophobic and fire resistant properties', Materials, 12(2), p. 447

Ishizuka, S., Sakai, Y. and Tanaka-Oda, A. (2014) 'Quantifying lignin and holocellulose content in coniferous decayed wood using near-infrared reflectance spectroscopy', Journal of Forest Research, 19(1), pp. 233237. doi: 10.1007/s10310-012-0386-6.

Kaur, P. J., Satya, S., Pant, K. K., Naik, S. N. and Kardam, V. (2016) 'Chemical characterization and decay resistance analysis of smoke treated bamboo species', European Journal of Wood and Wood Products. Springer Berlin Heidelberg, (March), pp. 10-14. doi: 10.1007/s00107016-1029-y.

Kothiyal, V., Bhandari, S., Ginwal, H. S. and Gupta, S. (2015) 'Multi-species NIR calibration for estimating holocellulose in plantation timber', Wood Science and Technology. Springer Berlin Heidelberg, pp. 769-793. doi: 10.1007/s00226-0150720-1.

Kumar, B., Bhardwaj, N., Agrawal, K., Chaturvedi, V. and Verma, P. (2020) 'Current perspective on pretreatment technologies using lignocellulosic biomass: An emerging biorefinery concept', Fuel Processing Technology, 199(July 2019). doi: 10.1016/j. fuproc.2019.106244.

Liang, L., Wei, L., Fang, G., Xu, F., Deng, Y., Shen, K., Tian, Q., Wu, T. and Zhu, B. (2020) 'Prediction of holocellulose and lignin content of pulp wood feedstock using near infrared spectroscopy and variable selection', Spectrochimica Acta - Part A: Molecular and Biomolecular Spectroscopy. Elsevier B.V., 225, p. 117515. doi: 10.1016/j.saa.2019.117515.

Park, C. W., Han, S. Y., Choi, S. K. and Lee, S. H. (2017) 'Preparation and properties of holocellulose nanofibrils with different hemicellulose content', BioResources, 12(3), pp. 6298-6308. doi: 10.15376/ biores.12.3.6298-6308.
Purwita, C. A. and Sugesty, S. (2018) 'Pembuatan dan karakterisasi dissolving pulp serat panjang dari bambu duri (Bambusa blumeana)', Jurnal Selulosa, 8(01), p. 21. doi: 10.25269/jsel.v1i01.232.

Rabemanolontsoa, H. and Saka, S. (2011) 'Holocellulose determination in biomass', in Yao, T. (ed.) Zero-Carbon Energy Kyoto 2011. Tokyo: Springer, pp. 135-140. doi: 10.1007/978-4-431-54067-0.

Rabemanolontsoa, H. and Saka, S. (2012) 'Method applicable to characterize various biomass species in their chemical composition', in Proceedings of the 4th AUN/SEED-Net Regional Conference on Biotechnology Faculty of Engineering, Chulalongkorn University and Burapha University, Thailand, pp. 1-6.

Ramawat, K. G. and Ahuja, M. R. (2016) 'Fiber plants: biology, biotechnology and applications', Sustainable Development and Biodiversity, 13, p. 263. doi: 10.1007/978-3319-44570-0.

Ritter, G. J. and Kurth, E. F. (1933) 'Holocellulose, total carbohydrate fraction of extractive-free maple wood: Its isolation and properties', Industrial and Engineering Chemistry, 25(11), pp. 1250-1253. doi: 10.1021/ie50287a016.

Saka, S. and Mimori R (1994) 'The distribution of inorganic constituents in white birch wood as determined by SEM-EDXA.', Journal of the Japan Wood Research Society, 40(1), pp. 88-94. Available at: https:// jglobal.jst.go.jp/en/detail?JGLOBAL ID $=200902153323266320 \quad$ (Accessed: $\overline{9}$ February 2021).

Sari, Y. W., Syafitri, U., Sanders, J. P. M. and Bruins, M. E. (2015) 'How biomass composition determines protein extractability', Industrial Crops and Products. Elsevier B.V., 70, pp. 125-133. doi: 10.1016/j.indcrop.2015.03.020.

Schmidt, E. and Graumann, E. (1921) 'Incrusting substances of plants substances. I. Methods for the preparation of pure plant skeletal', Deusche Chemische Gesellschaft Berichte, 54, pp. 1860-1873.

Sunardia, Istikowatib, W. T. and Sari, D. I. (2019) 'Extraction of $\alpha$-cellulose from Eleocharis dulcis holocellulose using $\mathrm{NaOH}$ and $\mathrm{KOH}$ ', Journal of Physics: Conference Series, 1(1397), pp. 1-7. doi: 10.1088/17426596/1397/1/012031.

Suzuki, M. (1953) 'A study on the deviation between yield and lignin contents of holocellulose', Journal of the Japanese Technical Association of the Pulp and Paper Industry, 7(1), pp. 9-14. 
Taflick, T., Schwendler, L. A., Rosa, S. M. L., Bica, C. I. D. and Nachtigall, S. M. B. (2017) 'Cellulose nanocrystals from acacia barkInfluence of solvent extraction', International Journal of Biological Macromolecules. Elsevier B.V., 101, pp. 553-561. doi: 10.1016/j.ijbiomac.2017.03.076.

Taylor, M. C., White, J. F., Vincent, G. P. and Cunningham, G. L. (1940) 'Sodium chlorite: Properties and reactions', Industrial and Engineering Chemistry, 32(7), pp. 899-903. doi: 10.1021/ie50367a007.

Thiex, N. J., Manson, H., Anderson, S. and Persson, J. A. (2002) 'Determination of crude protein in animal feed, forage, grain, and oilseeds by using block digestion with a copper catalyst and steam distillation into boric acid: Collaborative study', Journal of AOAC International, 85(2), pp. 309-317. doi: 10.1093/jaoac/85.2.309.

Timell, T. E. (1961) 'Isolation of galactoglucomannans from the wood of gymnosperms', Tappi, 44, pp. 88-96.

Vaz, R. P., de Souza Moreira, L. R. and Ferreira Filho, E. X. (2016) 'An overview of holocellulose-degrading enzyme immobilization for use in bioethanol production', Journal of Molecular Catalysis B: Enzymatic. Elsevier B.V., 133, pp. 127135. doi: 10.1016/j.molcatb.2016.08.006.

White, J. F., Taylor, M. C. and Vincent, G. P. (1942) 'Chemistry of Chlorites', Industrial \& Engineering Chemistry, 34(7), pp. 782792. doi: 10.1021/ie50391a003.
Wise, L. E. and Jahn, E. C. (1942) Wood Chemistry. 2nd edn. New York: Reinhold.

Wise, L. E., Maxine, M. and D'Addieco, A. A. (1946) 'Chlorite holocellulose, its fractionation and bearing on summative wood analysis and on studies on the hemicelluloses', Paper Trade Journal. doi: 10.1006/jsbi. 1999.4118.

Wu, T., Fang, G., Liang, L., Deng, Y., Lin, Y. and Xiong, Z. (2018) 'Analysis of mixed pulping raw materials of Eucalyptus globulus and Acacia mangium by near infrared spectroscopy technique combined with LASSO algorithm', BioResources, 13(1), pp. 1348-1359. doi: 10.15376/ biores.13.1.1348-1359.

Yang, X., Berthold, F. and Berglund, L. A. (2019) 'High-density molded cellulose fibers and transparent biocomposites based on oriented holocellulose', ACS Applied Materials and Interfaces. American Chemical Society, 11(10), pp. 10310-10319. doi: 10.1021/ acsami.8b22134.

Yoshihara, K., Kobayashi, T., Fujii, T. and Akamatsu, I. (1984) 'A novel modification of Klason lignin quantitaitve method', Japan Tappi Journal, 38(4), pp. 466-475. doi: 10.2524/jtappij.38.466. 